\title{
Implementation of the "dacha" law on agricultural lands and lands of populated areas
}

\author{
Natalya Cherezova $^{1 *}$, Irina Guzeva ${ }^{1}$, Alevtina Shirokova ${ }^{1}$ \\ ${ }^{1}$ Department of Geodesy and Cadastral Activities, Industrial University, \\ Lunacharskogo Street, Building 2, Room 103, Tyumen, 625000, Russia, \\ cherezovanv@tyuiu.ru
}

\begin{abstract}
Since January 1, 2019, Federal Law No.217 dated July 29, 2018 "On the introduction by citizens of gardening and gardening for their own needs and on amending certain legislative acts of the Russian Federation" (hereinafter referred to as Law No.217). Changes that occurred with gardening and dacha plots in connection with the adoption of the new federal law caused a number of problems with its implementation. This law has caused a big resonance among citizens, and among management structures, and among the community of cadastral engineers. Land plots that are located in the dacha and garden associations now fall into the development areas of individual and low-rise residential buildings, blocked residential area development. And houses on these sites can acquire the status of individual houses. In this regard, there will be and will arise many questions and problems with the use and management of territories and the registration of rights to real estate.
\end{abstract}

\section{Introduction}

Given the properties of the earth, man learned to use them for good [1]. The garden and garden movement in Russia has a rather long and difficult history. Presumably, the concept of "dacha" is associated with the All-Empire General Survey in Russia, which took place in the XVIII - XIX centuries [24]. In Russian, the word "cottage" appeared relatively recently. Until the XVIII century, it meant the land, given to someone in possession. V.I. Dahl the term "cottage" is mentioned in the sense of distribution of something, and only at the very end is the meaning of "country house" [20]. The history of the development of the country economy in Russia includes several stages:

Stage I: XVIII - XIX century. At the first stage, dachas most often acted as additional housing serving to show prestige and rest.

Stage II: in the second third of the XIX century, with the beginning of urbanization and industrialization, the number of factories and plants increased, profitable houses appeared. For the summer and the weekend, everyone who could afford it, tried to send families to nature. At the same time there was an improvement in the transport system, as there was regular communication with the suburbs. Thus, the development of the country economy was promoted by the development of capitalism in Russia and some environmental degradation [17]. 
Stage III: in the late XIX - early XX century. wealthy people still rested in patrimonial nests and abroad, but for most people of moderate means (officials, officers, representatives of the liberal professions) cottages were the only opportunity to relax and be in nature. They were not only their own, but also removed for a certain period.

Stage IV: the beginning of the First World War - NEP. The land was nationalized by the state and was recognized as an object of state ownership. But life in the country has become a habit among people, and even in the first post-revolutionary years, the dacha culture was weak, but continued to exist. The desire of the intelligent urban population to go somewhere for the summer has been preserved. Country construction continued to develop in the 1920s.

The events of our country, since 1917, have determined the direction of development of our society. However, the Great Patriotic War made its own adjustments - all forces were thrown to the defense and defense of the Fatherland.

Stage V: the beginning of the 20s - 1945. With the introduction of the NEP in Russia, the country life and country building not only revived, but also acquired a large scale. "Country idea" seized the masses. By a decree of the Central Executive Committee and the Council of People's Commissars of the RSFSR of June 14, 1927 "On Suburban Villages" [14], it was first defined what a "suburban village" is. Thus, holiday villages are recognized settlements located outside the city limits and having the main purpose of serving cities as sanatoriums or summer vacation places, if agriculture is the main occupation for no more than $25 \%$ of the adult population [17].

The lands under the existing dacha settlements assigned to this category on the basis of the said decree, as well as the land required for the organization of new summer settlements, were allocated to the settlements in the manner established for land allocation to cities (Articles 144-146 and Art. 153 of the RSFSR ). Land relations in holiday villages were regulated on the basis of the Regulations on land regulations in cities. The allocation of land plots to dacha-building cooperatives was carried out in accordance with the decree of the Central Executive Committee and the Council of People's Commissars of the RSFSR of August 1, 1932 "On the provision of land plots for construction to institutions, enterprises, and organizations of the socialized sector" for permanent use [15].

As a rule, large land plots were allocated to cottage-building cooperatives to accommodate entire cooperative villages consisting of many (sometimes several hundred) cottages. At the same time, the arrays allocated to villa-building cooperatives included not only manor plots intended for servicing individual cottages, but also land for business and service buildings of the cooperative itself, as well as streets, lanes and entrances to the cottages.

After the war, there were not enough products and, as an aid, in order to grow agricultural products for the townspeople, horticultural and dacha cooperatives and societies began to form (in everyday life, dachas) [25]

Stage VI: 1945-1991 After the war, the "dacha idea" embraced almost all strata of the urban population. Since the 60s. XX century during the Civil Code of the RSFSR of June 11,1964 [19] the land, its subsoil, water and forests were still in the exclusive ownership of the state and were provided only for use (Article 95). The RSFSR Land Code (Art. 74, 75) provided that land for collective gardening and gardening was provided from agricultural lands, reserve lands, forest reserves or temporarily unused lands of industrial, transport and other non-agricultural enterprises and organizations and institutions. Moreover, although the plots were not provided in the property, country and garden buildings could be sold by citizens [17]. Since 1958, the main regulatory act after the Decree "On Land", regulating the dacha construction, was the Resolution of the Council of Ministers of the USSR dated March 20, 1958 "On housing and cottage and construction cooperation" [12]. 
This act established that cottage building cooperatives (hereinafter referred to as DSK) are organized at the request of enterprises, institutions and organizations, and are registered with the executive committees of local Councils of Workers' Deputies on their decisions. In addition, the Circular of the Ministry of Public Utilities of the RSFSR of December 22, 1953, No. M-03-21442 "On the procedure for using land plots in DSC dachas" [13] gave explanations on the special procedure for using a land plot by two or more DSK members residing in one cottage possession. All land plots allocated in the prescribed manner for the construction of cottages on the right of cooperative ownership were issued to citizens on the basis of membership and subject to full payment of the share. In this case, a member of the cooperative was forbidden to transfer the occupied building and the land servicing it to another person. The maintenance and improvement of the land plot was carried out by shareholders on equal terms, regardless of the size of the unit and the occupied living space, in compliance with all fire-prevention, sanitary and external improvement rules.

When L.I. Brezhnev horticultural partnership received official permission to build a "summer garden house." Summer and garden construction is becoming widespread throughout the Soviet Union. Moreover, in the 1960s, it became "one of the types of housing cooperation" [21]. However, by the Decree of the Council of Ministers of the USSR of December 30, 1960 "On the individual construction of summer cottages" [11], the widespread withdrawal of land plots to individuals for individual country construction was prohibited, and all sales of country houses to state, cooperative and public organizations were discontinued. The regulatory framework, which determines the order of land use in suburban areas, approximately the same as modern ones, began to gradually form only in the second half of the 20th century [19]

According to Wikipedia, "cottage" is a country house for city dwellers, not used for their permanent residence. The territories adjacent to the dacha were used for growing garden and vegetable crops.

At present, however, as in other socio-economic formations, the land issue still remains relevant for our society. In connection with the growth of the welfare of a part of the population, since the end of the 20th century, the process of individual housing construction has intensified, which has helped to attract public funds to meet the need for housing. An important role was played by the social program "Housing". Proof of this can serve the number of appeals of citizens and legal entities on the provision of land $[2,3,5]$.

\section{Methods}

Analyzing and comparing information on garden and dacha associations that exist at the moment, we can say with confidence that the adoption of the law raises not only many questions, but also a huge number of problems with its implementation.

The Federal Law of April 15, 1998 No. 66 - FZ "On Gardening, Gardening, and Country Non-Profit Associations of Citizens" (hereinafter referred to as Law No. 66-FL) delimited the concepts of a garden plot, a summer cottage and a plot for gardening (Figure 1) [9]. 


\begin{tabular}{|c|c|}
\hline $\begin{array}{l}\text { garden plot - a plot } \\
\text { provided to a citizen or } \\
\text { acquired by him for the } \\
\text { cultivation of fruit, } \\
\text { berries, vegetables, } \\
\text { melons or other crops } \\
\text { and potatoes, as well as } \\
\text { for rest (with the right to } \\
\text { build a residential } \\
\text { structure without the } \\
\text { right to register residence } \\
\text { in it and household } \\
\text { structures and facilities) }\end{array}$ & $\begin{array}{l}\text { cottage land - a plot provided } \\
\text { to a citizen or acquired by } \\
\text { him for the purpose of rest } \\
\text { (with the right to build a } \\
\text { residential building without } \\
\text { the right to register residence } \\
\text { in it or a residential house } \\
\text { with the right to register } \\
\text { residence in it and household } \\
\text { buildings and structures, as } \\
\text { well as the right to grow fruit, } \\
\text { berries, vegetables, melons or } \\
\text { other crops and potatoes) }\end{array}$ \\
\hline
\end{tabular}

garden plot - a plot provided to a citizen or acquired by him for the cultivation of fruit, vegetables, melons or other crops and potatoes, as well as for rest (with the right to build a residential structure without the right to register residence structures and facilities)

\author{
cottage land - a plot provided \\ to a citizen or acquired by \\ him for the purpose of rest \\ with the right to build a \\ the right to register residence \\ in it or a residential house \\ with the right to register \\ residence in it and household \\ buildings and structures, as \\ well as the right to grow fruit, \\ other crops and potatoes)
}
garden land - a plot provided to a citizen or acquired by him for the cultivation of berries, vegetables, melons or other crops and potatoes (with or without the right to build a non-capital residential building and household buildings and structures depending on the permitted use of the land plot determined during zoning of the territory)

Fig. 1. Basic concepts in accordance with Federal Law No. 66 "On Gardening, Gardening, and Dacha Non-Profit Associations of Citizens".

This Law not only simplified the procedure for registration of rights to land plots and real estate objects located on it, but also solved the housing problems of citizens, which undoubtedly aroused interest among the urban population. Some citizens, in order to improve their living conditions, moved to their plots in houses, cabins, some built individual houses for further residence therein $[9,10]$.

"Dacha" plots were acquired both individually and through organizations and enterprises. In Tyumen, for example, there are such partnerships (societies, cooperatives), land plots in which were provided to citizens from enterprises: Medic, Avtopribor, Avtomobilist, Shipbuilder, and others.

On the territory of the municipal formation of the city district of Tyumen, the number of existing horticultural and dacha associations is 189 including societies and cooperatives, of which: 167 horticultural non-profit partnerships (SNT), 21 summer non-profit partnership, one gardening. Of these, 60 associations are within the boundaries of the settlement of the city of Tyumen.

Some of them entered the territory of the municipal formation of the urban district of Tyumen at the expense of the joined lands of the Tyumen district, and three were again created: garden, dacha, garden (in the area of Big Tsarevo Lake). The number of land plots in such associations is 60219, from which it can be concluded that every tenth resident of the city of Tyumen has a land plot for these purposes within the city district. At the same time there is a significant number of such associations outside the boundaries of the urban district within $60 \mathrm{~km}$ in different directions from the city (as of 04/09/2013) [23]

Most of the territories of existing horticultural and dacha associations already have a working engineering and transport infrastructure. In case of a need in areas that are in the society and are not used or not mastered, citizens can apply to existing associations and (or) acquire such areas within the framework of civil law relations.

The procedure for working with citizens in need of obtaining garden, vegetable garden or dacha land plots is regulated by: Federal Law of April 15, 1998 No. 66-FL "On Horticultural, Gardening and Dacha Non-Commercial Associations of Citizens"

However, this situation did not satisfy the needs of citizens who want to live in the private sector. For example, in the city of Tyumen, as of $01 / 01 / 2019$, the number of appeals for only country, garden land plots or land plots for horticulture was about 30 thousand. But Law No. 66 - FZ was temporary and had a fixed time frame for its implementation. 


\section{Results and Discussion}

Since January 1, 2019, Federal Law No. 217-FL dated July 29, 2018 "On the introduction by citizens of gardening and gardening for their own needs and on amending certain legislative acts of the Russian Federation" (hereinafter referred to as Law No. 217-FL) [8]. This law has caused a great resonance among citizens, and among management structures, and among the community of cadastral engineers.

The subject of Law No. 217-FL of the Law is the regulation of relations arising in connection with the maintenance by citizens of gardening and horticulture for their own needs.

Article 3 of this Law introduced the following concepts:

1) garden plot - a plot intended for the rest of citizens and (or) the cultivation of citizens for their own needs of crops with the right to accommodate garden houses, residential buildings, outbuildings and garages;

2) a garden house is a seasonal use building, intended for citizens to satisfy household and other needs associated with temporary residence in such a building;

3) farm buildings - sheds, bathhouses, greenhouses, sheds, cellars, wells and other structures (including temporary ones) designed to meet household and other needs;

4) a garden plot of land - a plot intended for the rest of citizens and (or) the cultivation of citizens for their own use of crops with the right to place farm buildings, which are not objects of real estate, intended for storing inventory and harvest of crops;

5) property of common use - capital construction objects and general-purpose land plots located within the boundaries of the territory where citizens carry out gardening and horticulture for their own needs, which can be used exclusively to meet the needs of citizens leading horticulture and horticulture (passage, passage, heat and electricity supply) energy, water, gas, water disposal, security, municipal solid waste collection and other needs), as well as movable things created (with under construction) or acquired for the activity of a gardening or gardening non-profit partnership;

6) general purpose land plots - land plots. being property of common use provided for by the approved documentation on planning of the territory and intended for common use by the right holders of land plots located within the boundaries of the territory owned by citizens for gardening and horticulture for their own needs, and (or) intended for housing other property of common use;

7) the territory of reference by citizens for horticulture or gardening for their own needs the territory, the boundaries of which are determined in accordance with the territory planning documentation approved for this territory

Prior to the adoption of Law No. 217-FZ, gardening activities of citizens were regulated by the civil code and Law No. 66-FZ. Until 2019, 9 forms of organizational and legal activity were defined: ODNP, DNT, SNT, ONT, DPK, SEC, OPK, DNP, SDNP. With the adoption of the new 217-FZ, the number of forms of garden and garden activities has decreased to 2 - SNT (garden non-profit partnership) and ONT (garden non-profit partnership).

Based on the foregoing, Law No. 217-FZ excludes "cottage" land plots, attributing these land plots to the development areas by individual and low-rise residential buildings blocked by the residential area construction. And houses on these plots can acquire the status of individual houses - objects of individual housing construction [7.26]. The parameters of such an object are also determined:

1) the building, which is a single object and does not imply the possibility of its division into separate objects;

2) the maximum permissible height of a residential building is up to 20 meters (and not more than three floors); 
3) the building is intended for citizens and includes rooms and ancillary facilities.

This situation is acceptable only for land settlements. In this case, the procedure for registering land plots will be determined by land legislation, while territorial planning documents will be distributed to the territory.

In most cases, the discontent of citizens associated with the following points:

a) re-registration of documents;

b) additional financial costs for the re-registration of documents, respectively, additional time costs;

c) an increase in the size of land payments;

d) reduction of land use due to the construction of engineering and transport infrastructures, the issue of compensation payments is not worked out;

e) the incorrect behavior of some chairmen of partnerships who use the ignorance of the laws of the majority of members of such partnerships and use the situation for their own selfish purposes;

f) if there is another housing, there is no possibility of residence in the house;

g) insufficient period of the transition period.

If the dacha companies (partnerships) are outside the territory of the settlement and are "cross-lane", the provisions of the Federal Law of July 29, 2018 No. 217-FZ Federations "do not apply. In this situation, dacha non-profit partnerships (companies) should change the form of organizational interaction to horticultural or gardening. The procedure for reissuing documents for land plots will include: changing the category of land from agricultural purpose to the land of populated areas, developing territorial planning documents for the territories included in the populated area, and then resolving the issue regarding land plots and buildings located on them. This is confirmed by the Town Planning Code of the Russian Federation [2]. However, the transfer of agricultural land to the land of settlements is problematic $[3,6,7]$.

In other words, in case the land plot (previously country cottage plot) with the house does not fall within the boundaries of the settlement and is "inter-band", then it is not possible to register the house as an object of individual housing construction. A positive point is that land payments will remain the same, although it is necessary to spend time on re-issuing documents. Financial costs will also occur.

For management structures, there are also problems in these cases, namely, that information on changing the type of association is not communicated to them [4]. That is, there is no relevant information from the executive authorities. The information database contains invalid data.

The transfer of dacha territories from agricultural lands to the category of settlements, as practitioners claim, is possible if the territory of the dacha community is adjacent to the border of the settlement [3]. This is confirmed by article 23 of the Town Planning Code of the Russian Federation "Content of the scheme of the master plan for a settlement and the master plan for a city okrug" by paragraph 2 "The preparation of a master plan can be carried out for individual towns and villages in the city okrug, with subsequent changes to the master plan, belonging to other parts of the settlement territory, urban district "[2]

Thus, the transfer of lands of dacha non-profit partnerships, the territory of which falls within the boundaries of a settlement, into the category of lands of residential development is inevitable. Inevitably, a change in the type of dacha non-profit partnership located on agricultural land (Figure 2). 


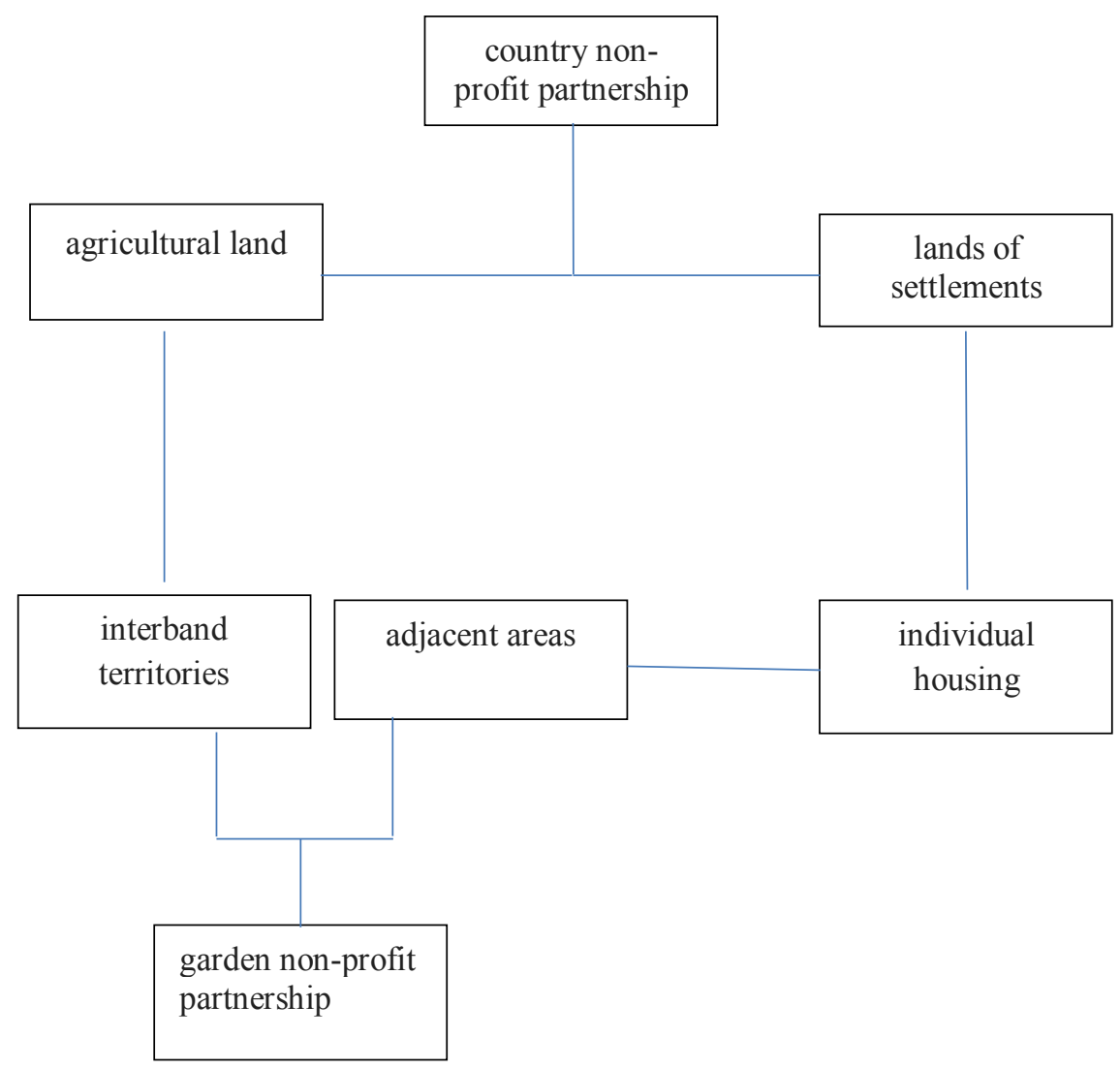

Fig. 2. The scheme of renewal of country non-commercial partnerships.

Development of territorial planning documents is a long process. The content of territorial planning documents is presented in Figure 3. As can be seen from the figure, the territorial district planning document is the master plan - the main urban planning document defining the conditions for forming the living environment, the direction and boundaries of territory development, zoning, engineering, transport and social infrastructure development, urban planning requirements for preserving historical objects in the interests of the population and the state. -cultural heritage and specially protected natural territories [22].

The content of the master plan, the preparation and approval of the master plan of the settlement, the master plan of the urban district is also regulated by the Town Planning Code of the Russian Federation [2]. 


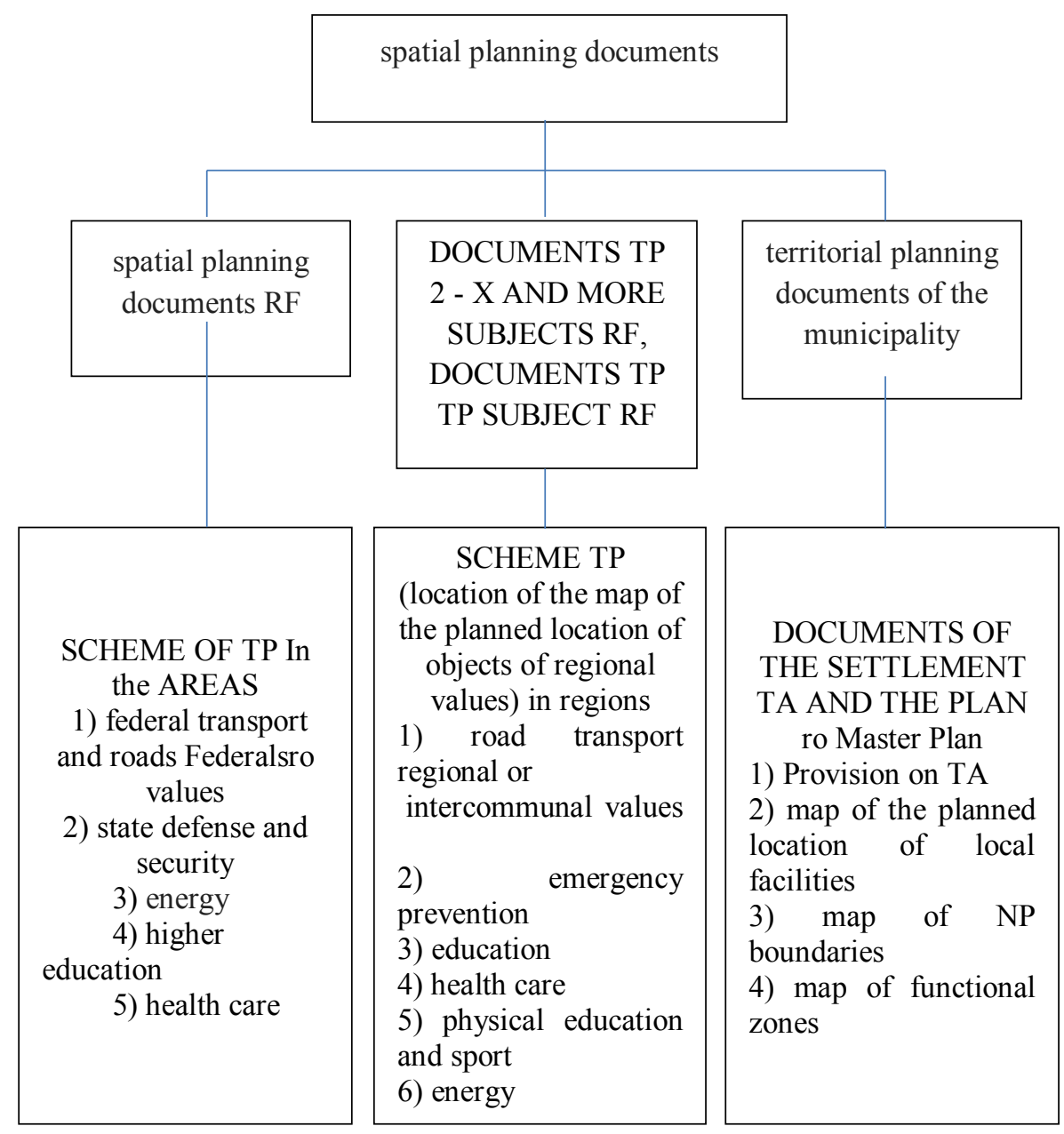

Fig. 3. Content of territorial planning documents.

In the territories of settlements, attention should be paid to garden non-profit societies, where today there are already cases of registration before the introduction of Law 217-FZ. How to deal with buildings (including "mansions" built on the territory of a gardening nonprofit partnership)? In this regard, in the information telecommunication network the Internet is a lot of reasoning. Practitioners say it is possible, but under the following conditions:

a) the territory of the horticultural non-profit partnership must be within the boundaries of the settlement;

b) the partnership must have developed and approved town planning regulations;

c) the building must meet the requirements of a residential building;

d) the availability of conditions for year-round living;

e) availability of documents with a positive decision: from Rospotrebnadzor, from fire inspection, BTI, administration of the locality.

Interesting is the issue of payment for a plot in the village: under a dwelling house in a residential building, "transferred" from a dacha partnership, and under a dwelling house located in a gardening partnership [4]. Maybe it is worth the territory of gardening nonprofit partnerships located in settlements, with residential buildings also translate into residential areas? Moreover, when expanding the territory of settlements, the location of 
some gardening partnerships turned out to be in developed urban areas. This situation repeats the fate of the territories under garage cooperatives: almost in the center of the settlements there are garages that have a non-aggressive effect on the environment and the appearance of the city. Currently, there is a lot of talk about it.

\section{Conclusions}

Summarizing the above, we can conclude that city dwellers, faced with a similar situation, are not ready to address such issues. It is necessary to intensify explanatory work among "summer residents and gardeners".

A good example is the event held in the city of Tyumen during the times of land reform "- an inventory of land in the private sector: a bus equipped with office equipment was allocated, which was planned to leave for the private sector, where the documents were drawn up in the field [7]. The specialists not only carried out explanatory work, but also replenished the information database, which is so necessary for making competent management decisions, at the same time solving the issue of replenishing the local budget.

Explanatory work will contribute to the less painful passage of changes in the functional purpose of the land and eliminate violations of the law not only from negligent chairmen, but also land users themselves.

When planning construction on such sections of residential buildings, stipulate town planning regulations providing for the future construction of the road network and engineering infrastructure facilities.

Also required is a regulatory act that allows for the exchange of information with the tax inspectorate on the change in the form of organizational interaction.

\section{References}

1. The Constitution of the Russian Federation, http // www.consultant.ru

2. Town Planning Code of the Russian Federation, www.consultant.ru

3. Land Code of the Russian Federation, http // www.consultant.ru

4. Tax Code of the Russian Federation, http // www.consultant.ru

5. Federal Law of July 21, 1997 No. 122-FL, http // www.consultant.ru

6. Federal Law of 24.07.2007 No. 221-FL, http // www.consultant.ru

7. Federal Law of July 13, 2015 No. 218-FL, http // www.consultant.ru

8. Federal law of 29.07. 2017 No. 217-FL, http // www.consultant.ru

9. Federal Law of April 15, 1998 N 66-FZ, http // www.consultant.ru

10. Federal law of June 30, $2006 \mathrm{~N} 93-\mathrm{FZ}$

11. Union of Writers of the USSR 1, 2 (1961)

12. Union of Writers of the USSR 5, 47 (1958)

13. Union of Writers of the USSR 12, 127 (1953)

14. Collection of laws of the RSFSR 8, 70 (1928)

15. Collection of laws of the RSFSR 9, 87 (1932)

16. Collective gardening and horticulture: Collection of regulations (Legal. lit., Moscow, 1987)

17. A.V. Belov, Bulletin of the Moscow Regional University. Series: Historical and political sciences 1, 105-117 (2007) 
18. A.I. Butovetsky, E.L. Kovaleva, Commentary on the law "on horticultural, vegetable gardening and dacha non-profit associations of citizens (itemized), gorodazov.ru/File/2017/jkh/sad/komentsad.rtf

19. Bulletin of the Supreme Soviet of the RSFSR 24, 406 (1964)

20. V.I. Dal, Explanatory dictionary of the Russian language (Modern version, Moscow, 2000)

21. B.V. Erofeev, M.S. Lipetsker, Land use in cities, workers, cottage and resort villages (Moscow, 1959)

22. L.V. Kashkina, V.A. Kashkin, The foundations of urban planning. Design of urban environment: studies (Publishing Center "Academy", Moscow, 2017)

23. M.A. Reshetnikova, N.V. Cherezova, Modern problems of land cadastral activities, materials of the All-Russian scientific-practical conference, 82-89 (2018)

24. R.J. Struyk, K. Angelici, The Russian Dacha phenomen. Housing Studies 11(2), 233250 (1996)

25. History of civil law regulation of relations in the field of gardening, gardening and country building, http://domir.ru/rehkolovo/?file=sad-istoria.php

26. https://mhg.ru/sites/default/files/files/monitoring-zakonodatelstvo-08-2015.pdf 
